\title{
Regulatory mechanisms for absenteeism in the health sector: a systematic review of strategies and their implementation
}

This article was published in the following Dove Press journal:

Journal of Healthcare Leadership

9 November 2016

Number of times this article has been viewed

\author{
Angela N Kisakye' \\ Raymond Tweheyo' \\ Freddie Ssengooba' \\ George W Pariyo ${ }^{2}$ \\ Elizeus Rutebemberwa' \\ Suzanne N Kiwanuka' \\ 'Department of Health Policy Planning \\ and Management, Makerere University \\ School of Public Health, Kampala, \\ Uganda; ${ }^{2}$ Department of International \\ Health, Johns Hopkins Bloomberg \\ School of Public Health, Baltimore, \\ MD, USA
}

Background: A systematic review was undertaken to identify regulatory mechanisms aimed at mitigating health care worker absenteeism, to describe where and how they have been implemented as well as their possible effects. The goal was to propose potential policy options for managing the problem of absenteeism among human resources for health in low- and middleincome countries. Mechanisms described in this review are at the local workplace and broader national policy level.

Methods: A comprehensive online search was conducted on EMBASE, CINAHL, PubMed, Google Scholar, Google, and Social Science Citation Index using MEDLINE search terms. Retrieved studies were uploaded onto reference manager and screened by two independent reviewers. Only publications in English were included. Data were extracted and synthesized according to the objectives of the review.

Results: Twenty six of the 4,975 published articles retrieved were included. All were from highincome countries and covered all cadres of health workers. The regulatory mechanisms and possible effects include 1) organizational-level mechanisms being reported as effective in curbing absenteeism in low- and middle-income countries (LMICs); 2) prohibition of private sector activities in LMICs offering benefits but presenting a challenge for the government to monitor the health workforce; 3 ) contractual changes from temporary to fixed posts having been associated with no reduction in absenteeism and not being appropriate for LMICs; 4) multifaceted work interventions being implemented in most settings; 5) the possibility of using financial and incentive regulatory mechanisms in LMICs; 6) health intervention mechanisms reducing absenteeism when integrated with exercise programs; and 7) attendance by legislation during emergencies being criticized for violating human rights in the United States and not being effective in curbing absenteeism.

Conclusion: Most countries have applied multiple strategies to mitigate health care worker absenteeism. The success of these interventions is heavily influenced by the context within which they are applied.

Keywords: absenteeism, health workers, regulatory mechanisms, systematic review

\section{Introduction}

Absenteeism in the health sector frequently referred to as the loss of scheduled time due to unscheduled work absence ${ }^{1}$ has remained a long-standing challenge worldwide. Absenteeism also includes staff taking more leave than is necessary. In Norway, United Kingdom, and United States of America absenteeism has been attributed to subjective health complaints. ${ }^{2,3}$ Describing absenteeism behavior, Rogers et $\mathrm{al}^{4}$ postulate that an employee's attendance behavior is a function of two key variables: 1) ability to attend, and 2) motivation to attend. The employee who is willing to attend could be affected
Correspondence: Angela N Kisakye Department of Health Policy Planning and Management, Makerere University School of Public Health, New Mulago Hill Hospital Complex, PO Box 7072,

Kampala, Uganda

Tel +25678537375 I

Fax +256 4I 4540633

Email akisakye@musph.ac.ug 
by negative pressures including their affective response to the job situation (internal motivation) and varying levels of external pressure from unavoidable (eg, illness, accidents, family responsibility) or avoidable pressures (eg, stress due to job role, scope, leadership style among other administrative concerns). ${ }^{4}$

Absenteeism reduces the effectiveness of health care provision and compromises the quality of services because fewer workers are left on duty, resulting in work overload or interrupted service delivery. Governments in developing countries spend about $10 \%$ of their total budgets on public health care; however, dissatisfaction is often expressed over the performance and quality of health services., ${ }^{5,6}$

Globally, about $7 \%$ of health care workers are reported to experience at least one spell of absence each week. ${ }^{1}$ In recent times, absenteeism has been studied among health care workers in low- and middle-income countries (LMICs), showing high rates like $25 \%$ in Kenya. ${ }^{7}$ Unannounced visits made to health facilities with the intention of discovering what fraction of medical professionals were present at their assigned posts showed absence rates of $35 \%$ in Bangladesh, $37 \%$ in Uganda, and $40 \%$ in India and Peru. ${ }^{5}$ Absence is highest among the health professionals, particularly doctors and pharmacists, who should be mentoring other workers. Females are reported to be more absent, though for shorter durations. ${ }^{1,8}$ Moreover, absenteeism is less frequent during morning hours compared to the afternoons ${ }^{5}$ and is less prevalent among older health care workers, even though they are absent for longer durations. ${ }^{8}$ Absenteeism is becoming increasingly important during pandemic threats, with health care workers absenting themselves from health care facilities due to unwillingness to provide care amid increased occupational risks. ${ }^{9}$

In the context of this review, absenteeism was limited to health care workers who were reported unavailable without authorization at their primary health-related job during scheduled time for durations longer than half a working day, or absence due to illness, which could not be verified.

\section{Rationale for the review}

Health care workers are inadequate in numbers, skill-mix, and distribution, especially in LMICs. ${ }^{4,10-12}$ Absenteeism among health care workers causes disruption of health care service delivery ${ }^{6,13,14}$ and economic losses, ${ }^{5}$ particularly given the already limited numbers and inequitable distribution of health care workers. A review by Michie and Williams ${ }^{3}$ identified interventions that reduce work-related psychological ill health and absence among various sector workers as well as work-based regulatory mechanisms such as vaccination. ${ }^{15}$ Some of these interventions could offer lessons for managing absenteeism among health workers in LMICs.

The objectives of this review were as follows: 1) to identify regulatory mechanisms that address health care worker absenteeism from any causes, and 2) to describe how they have been implemented and their possible effects. The overall aim of the review was to identify and propose policy options for reducing the problem of absenteeism among human resources for health in LMICs. The absenteeism mechanisms described in this review are at the local workplace and broader national policy level. This absenteeism review was, however, not focused on quantifying the effect of absenteeism regulatory mechanisms or the economic consequences of absenteeism. These aspects could be the focus of future studies and systematic reviews.

\section{Causes of health worker absenteeism}

In the United States, Costa Rica, Canada, and Africa, several reasons have been advanced to explain health care worker absenteeism; however, the most widely acknowledged are illness or sickness and injury. ${ }^{1,8,14,16}$ Although many studies relate absenteeism to illness or disease, ${ }^{17}$ Thulensius and Grahn ${ }^{18}$ report a poor correlation between work capacity and disease concepts. Chaudhury et $\mathrm{al}^{19}$ reporting on multicountry surveys in LMICs that conducted unannounced visits at health facilities found that illness contributed to only $4 \%$ of health worker absenteeism. In addition, administrative causes such as infrequent supervision or inspection of health facilities, nonavailability of potable water, and absence of staff housing and working in rural locations are important contributors to absenteeism in LMICs. ${ }^{19}$

In developed countries however, low back pain is a major contributor to health care worker absenteeism, for instance, in Spain ${ }^{20}$ and Belgium. ${ }^{21}$ Psychological ill-health reportedly contributes between $17 \%$ and $33 \%$ of absenteeism. ${ }^{3}$ Other important potential causes reported include dissatisfaction with earnings and dual practice, ${ }^{8,14,22}$ pandemic threats including terrorist, chemical, biological, radiological, and nuclear events, ${ }^{9,14}$ excessive workload with a poor working environment, ${ }^{8}$ organizational type, culture, and size. ${ }^{8}$ Aldana and Pronk $^{23}$ describe health risks and failure to participate in fitness and health promotion programs as contributors to absenteeism.

At the macrolevel, public service reforms have been reported to have a potential effect on absenteeism in the health sector. Ngufor ${ }^{24}$ and Ssengooba et $\mathrm{al}^{25}$ describe how sector reforms have in some instances led to demotivated health workers, resulting in absenteeism. The most prominent 
consequence of absenteeism is that it worsens the problem of limited health care worker numbers especially in the public sector. ${ }^{6,14}$ Sibbald $^{14}$ in an evaluation of the effects of absenteeism in the Canadian health system showed that health care workers were one and a half times more likely to be absent from work due to illness or injury and were generally more dissatisfied with their jobs than workers in other sectors. They estimated that health care workers were absent $7.2 \%$ of the time (11.8 days per year) compared to $4.8 \%$ (6.7 days per year) for other workers.

Harter $^{26}$ used the human resource framework constructs to emphasize that employees' job satisfaction and absenteeism were largely predicted by their commitment to the organization and the perceived autonomy. The purpose of the framework is to enable the organizations of the United Nations common system to manage their human resources effectively. The framework also provides the organizations with a holistic conceptual base from which to take action in one or more areas of human resources management reform. It can therefore be used to form the basis of the organizations' future work on human resources policies and procedures. Harter ${ }^{26}$ further proposed strategies to be employed in absenteeism control programs, which were based on the four paradigms of organizational behavior: 1) the symbolic strategy that promotes change of organization culture to one that does not tolerate excessive employee absence; 2) the structural framework, which defines clear performance expectations where the human resource managers devise measures to ensure employee adherence to policies and procedures laid out for absenteeism; 3) the political framework, in which Harter ${ }^{26}$ proposes the use of shared governance with employees as a strong predictor for organizational cultural change. It could include bargaining with employees and creating rewards and punishments for different levels of attendance; and lastly 4) the human resource framework, which emphasizes support, empowerment, staff development, and responsiveness.

\section{Methods}

This review sought to describe absenteeism regulatory mechanisms documented in journal articles, reports, editorials, working papers, and reviews. Studies of regulatory mechanisms and their implementation were eligible for inclusion, specifically:

1. Studies assessing statistical association such as surveys and case-controlled studies.

2. Process evaluations of implementation of regulatory mechanisms addressing absenteeism.
3. Opinion surveys involving intervention implementers and health providers about the actual or potential influence of the regulatory mechanisms.

4. Randomized controlled trials, uncontrolled trials, interrupted time series, before and after studies on the effectiveness of absenteeism interventions, and lastly studies of the views of health workers or patients.

Studies that did not report on absenteeism regulatory mechanisms and/or whose implementation did not include professional health workers and used a language other than English were excluded. Studies evaluating effectiveness are only used to inform the discussion (Figure 1).

\section{Identification of potential studies: search strategy}

Studies were identified from bibliographic databases. Reference lists of key papers, commercially available and specialized electronic databases such as MEDLINE, EMBASE, ERIC, Social Science Citation Index, CINAHL, Google Scholar and Google (EPPI-Centers bibliographic database), and the Cochrane Library were also searched. Relevant health policy and health administration-related websites were searched including The Health Management Information Consortium, World Health Organization Library Information System, World Bank, and Human Resources for Health Websites. The African Index Medicus was searched to obtain publications from the African region. The search strategy combined controlled vocabulary terms and free text to expand the scope of potential relevant articles. The search terms included the following: work, organization, administration, government, private, health worker, absenteeism, absence, absentee, absen*, presenteeism, present*, sick leave, illness, contract, employment, dual practice, legislation, incentive, policies, codes, prohibition, regulations, regulat*, restrict*, guide*, ban and practic*. Searches were applied from the starting date of each database to July 2014.

\section{Data management}

All relevant studies identified through electronic searches were retrieved and uploaded onto the Reference Manager software version 12 (Thomson Reuters, Philadelphia, PA, USA). After inclusion and exclusion criteria were applied, all included studies were uploaded onto EPPI reviewer software for coding. Codes included, among others, study design, setting, study population, main findings, and type of regulation. All included studies were used in the descriptive mapping of regulatory mechanisms of absenteeism. 


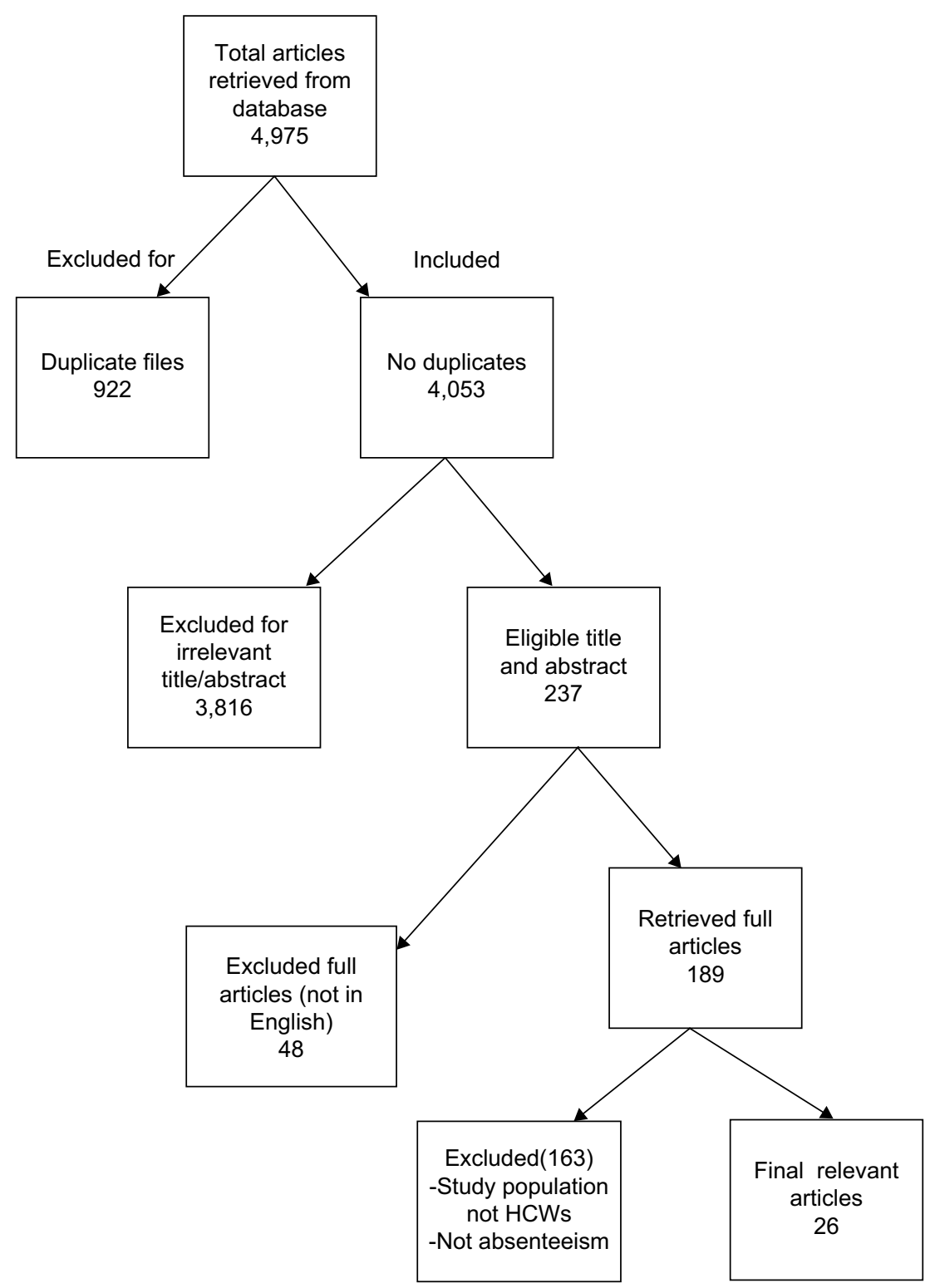

Figure I Chart showing included and excluded studies.

Abbreviation: $\mathrm{HCWs}$, health care workers.

\section{Synthesis of evidence}

Absenteeism regulatory mechanisms identified from the included reports were initially described according to their setting (context), population, variation in approach, and outcomes. Studies with similar approaches to managing absenteeism were grouped together.

\section{Results}

\section{Absenteeism regulatory mechanisms}

The search retrieved 4,975 studies. Of these, 922 were excluded because they were duplicate articles across the databases. An additional 3,816 studies were excluded for having content irrelevant to our objective, 48 studies were excluded because they did not report in English, and 163 studies were excluded because they did not include professional health workers (medical doctors, nursing professionals, midwifery professionals, dentists, and pharmacists). Studies of regulatory mechanisms addressing absenteeism and their implementation were assessed for their quality using a subset of criteria adapted from Harden et al. ${ }^{27}$ These criteria focused on the clarity of the description of the context, population, and the methods used to collect and analyze data. The reviewers relied heavily on the judgments and learning of the authors of the included studies and applied this minimum set of quality criteria.

While absenteeism is described in both low- and highincome countries, all the studies included in this review were conducted in high-income countries (HICs), with none from 
LMICs because there were no studies that described absenteeism regulatory mechanisms from LMICs. Twelve studies were from the United States, ${ }^{2,4,26,28-35}$ three from the United Kingdom, ${ }^{3,8,36}$ two from Canada, ${ }^{37,38}$ three from Finland, ${ }^{39-41}$ one from Belgium, ${ }^{42}$ one from Sweden, ${ }^{43}$ one from Norway, ${ }^{44}$ one from Taiwan, ${ }^{45}$ one study was a multicountry study across the United Kingdom, the Netherlands, the United States, and Australia, while another was conducted across Germany, Holland, Spain, and the United Kingdom.

The studies included in this review described regulatory mechanisms for absenteeism in both the public and private sectors, for individual health care workers, eg, nurse managers, for solitary health care organizations as well as broader health care systems. These absenteeism regulatory mechanisms were grouped into seven major categories:

1. Organizational absenteeism policies that involve changes in organizational culture including attendance policies, outlining disciplinary procedures for absence, documenting the process for absence review, monitoring, audit and disciplining, or even dismissal/ forced retirement. In a review by Michie and West, ${ }^{46}$ implementation of the organizational absenteeism policy was reported in the United States, Australia, the Netherlands, and the United Kingdom. ${ }^{46}$ Other studies reported implementation of similar policy in the United Kingdom, Germany, Holland, Spain, and the United Kingdom. ${ }^{30-33,36,37,43-45,47,48}$

2. Restriction or prohibition of private practice was implemented in the United Kingdom, Spain, and France to reduce absenteeism among public health care workers. ${ }^{49}$

3. Changes in employment contracts from fixed to permanent post in Peru, Costa Rica, and Finland were implemented to regulate absenteeism. ${ }^{8}$

4. Work multifaceted regulatory mechanisms instituted as far back as the 1990s aimed at improving work environments and have been reported in Belgium. ${ }^{42}$ Stone et $\mathrm{al}^{29}$ also reported implementation of these strategies in Holland, Spain, Germany, the United Kingdom, and Finland. These strategies have also been implemented in the United States. ${ }^{30,41}$

5. Financial and incentive regulatory mechanisms characterized by providing financial rewards for good attendance were implemented among all cadres of health workers in the United Kingdom and the United States. ${ }^{26,34-36}$

6. Health intervention mechanisms such as vaccination and exercise programs that aim at reducing work-related ill-health and absence among health workers have been implemented in the United Kingdom, ${ }^{2,30,33}$ Norway, ${ }^{44}$ Taiwan, ${ }^{45}$ Sweden, ${ }^{43}$ and Finland. ${ }^{39}$

7. Mandatory attendance and surveillance of absenteeism behavior during disaster, which was proposed in HICs. ${ }^{28}$ In the United States, the mechanism faced criticism from human rights advocates who raised concern about public health liberties.

Table 1 describes the landscape of regulatory mechanisms that have been instituted or proposed to curb absenteeism among health care workers globally.

\section{Implementation of proposed or implemented regulatory mechanisms}

The different regulatory mechanisms described in this review varied in context, study population, and outcome. Some of the studies in this review described a single mechanism, while others described more than one mechanism. The mechanisms were supported by different factors and varied from place to place. This section details the implementation of the different regulatory mechanisms and the factors that supported or hindered implementation.

\section{Organizational policies to regulate absenteeism}

The use of organizational policies to regulate absenteeism was described in eight out of 26 studies in this review. The mechanism was implemented by instituting policy changes in organizational culture. It involves organizational leaders working with their employees to collectively define desired organizational culture, which they then strategically align with the organization's vision, mission, and objectives as well as setting exemplary actions and tempo. Employees and their managers were further encouraged to schedule their own leave days off, while keeping in mind the organization's schedules. This approach took into consideration employee needs, which then did not conflict with organizational programs. In some instances, a leave day bank was replenished if the employee maintained a clean attendance record over a consecutive 21-day working routine. In the United Kingdom, the Netherlands, United States, and Australia, the implementation of this mechanism affected all cadres of health workers and involved, 1) discussing with offenders and encouraging them to improve; 2) counseling and follow-up of employees' conduct; and 3) rewarding employees who improved in attendance. ${ }^{46}$ While in the United Kingdom, United States, Holland, Germany, and Spain, implementation of the organizational policies to regulate absenteeism involved, 1) instituting absenteeism policies for employees to sign and 
Table I Studies documenting absenteeism regulatory mechanisms in different contexts

\begin{tabular}{|c|c|c|c|c|}
\hline Regulatory mechanisms & Study & $\begin{array}{l}\text { Context/setting } \\
\text { Region: country }\end{array}$ & Study population & Study design \\
\hline \multicolumn{5}{|l|}{ I. Organizational policies } \\
\hline $\begin{array}{l}\text { I) Changing organizational } \\
\text { culture }\end{array}$ & $\begin{array}{l}\text { Michie and West, }{ }^{46} \text { Kivistö } \\
\text { et al, }{ }^{41} \text { Whitaker }{ }^{47}\end{array}$ & $\begin{array}{l}\text { HIC - UK, the } \\
\text { Netherlands, } \\
\text { USA, Australia }\end{array}$ & $\begin{array}{l}\text { All health care } \\
\text { workers, health care } \\
\text { organizations }\end{array}$ & Review \\
\hline \multirow[t]{2}{*}{$\begin{array}{l}\text { 2) Implementing } \\
\text { absenteeism policy }\end{array}$} & $\begin{array}{l}\text { Harter, }{ }^{26} \text { Curran and } \\
\text { Curran, }{ }^{34} \text { Stephens and } \\
\text { Burroughs }{ }^{35}\end{array}$ & HIC - USA & Nurses & $\begin{array}{l}\text { Editorial } \\
\text { Review }\end{array}$ \\
\hline & $\begin{array}{l}\text { Whitaker }{ }^{47} \\
\text { Johnson et } \mathrm{al}^{36} \\
\text { McDonald and Shaver }{ }^{48}\end{array}$ & $\begin{array}{l}\text { HIC - Holland, } \\
\text { Germany, Spain, USA } \\
\text { HIC - UK }\end{array}$ & $\begin{array}{l}\text { All health care } \\
\text { workers }\end{array}$ & $\begin{array}{l}\text { Literature review } \\
\text { Commentary }\end{array}$ \\
\hline \multirow[t]{3}{*}{$\begin{array}{l}\text { 2. Surveillance and referral to } \\
\text { occupational health services }\end{array}$} & $\begin{array}{l}\text { Donovan et } \mathrm{al}^{38} \\
\text { Whitaker } \\
\text { Johnson et } \mathrm{al}^{36}\end{array}$ & $\begin{array}{l}\text { HIC - Canada } \\
\text { HIC - Holland, } \\
\text { Germany, Spain, UK }\end{array}$ & $\begin{array}{l}\text { All health care } \\
\text { workers }\end{array}$ & $\begin{array}{l}\text { Retrospective cohort } \\
\text { Review }\end{array}$ \\
\hline & $\begin{array}{l}\text { Harter }^{26} \\
\text { McDonald and Shaver }{ }^{48}\end{array}$ & $\begin{array}{l}\text { HIC - UK } \\
\text { HIC - USA }\end{array}$ & $\begin{array}{l}\text { All health care } \\
\text { workers }\end{array}$ & $\begin{array}{l}\text { Literature review } \\
\text { Editorial }\end{array}$ \\
\hline & Kivistö et $\mathrm{al}^{41}$ & HIC - Finland & $\begin{array}{l}\text { All health care } \\
\text { workers }\end{array}$ & Commentary \\
\hline $\begin{array}{l}\text { 3. Contractual policies (fixed } \\
\text { term to permanent) }\end{array}$ & Virtanen et a $\mathrm{a}^{40}$ & HIC - Finland & $\begin{array}{l}\text { All health care } \\
\text { workers }\end{array}$ & Prospective cohort \\
\hline \multicolumn{5}{|l|}{$\begin{array}{l}\text { 4. Work multifaceted } \\
\text { approaches }\end{array}$} \\
\hline $\begin{array}{l}\text { I) Recurrent administrative } \\
\text { changes (supervisor, task, } \\
\text { shifts, location, etc) }\end{array}$ & Verhaeghe et $\mathrm{al}^{42}$ & HIC - Belgium & Nurses & $\begin{array}{l}\text { Cross-sectional study } \\
\text { nested in prospective study }\end{array}$ \\
\hline 2) Managing attendance & Stone et $\mathrm{a}^{29}$ & $\mathrm{HIC}$ - USA & Nurses & Cross-sectional study \\
\hline $\begin{array}{l}\text { 3) Allowing individual } \\
\text { control of absence }\end{array}$ & $\begin{array}{l}\text { Whitaker }{ }^{47} \\
\text { Allen }^{52}\end{array}$ & $\begin{array}{l}\text { HIC - Holland, } \\
\text { Germany, Spain, UK }\end{array}$ & $\begin{array}{l}\text { All health care } \\
\text { workers }\end{array}$ & Review \\
\hline \multirow[t]{2}{*}{ 4) Nonpunitive control } & Kivistö et $\mathrm{al}^{41}$ & HIC - Finland & $\begin{array}{l}\text { All health care } \\
\text { workers }\end{array}$ & Prospective survey \\
\hline & Rogers et $\mathrm{al}^{4}$ & HIC - USA & $\begin{array}{l}\text { All health care } \\
\text { workers }\end{array}$ & Literature review \\
\hline \multicolumn{5}{|l|}{ 5. Financial/incentive measures } \\
\hline $\begin{array}{l}\text { I) Rewarding good } \\
\text { attendance }\end{array}$ & Harter, ${ }^{26}$ Allen ${ }^{52}$ & HIC - USA & $\begin{array}{l}\text { All health care } \\
\text { workers }\end{array}$ & Editorial \\
\hline \multirow[t]{3}{*}{$\begin{array}{l}\text { 2) Combining reward and } \\
\text { coercive power }\end{array}$} & Johnson et $\mathrm{al}^{36}$ & $\mathrm{HIC}-\mathrm{UK}$ & $\begin{array}{l}\text { All health care } \\
\text { workers }\end{array}$ & Literature review \\
\hline & Rogers et $\mathrm{al}^{4}$ & HIC - USA & All health care & Literature review \\
\hline & Harter $^{26}$ & HIC - USA & workers & \\
\hline \multirow[t]{4}{*}{$\begin{array}{l}\text { 6. Addressing employee health } \\
\text { and safety }\end{array}$} & $\begin{array}{l}\text { Weingarten et al, }{ }^{33} \\
\text { Kramer et al, }{ }^{30} \text { Menzel and } \\
\text { Robinson }{ }^{2}\end{array}$ & HIC - USA & $\begin{array}{l}\text { All health care } \\
\text { workers }\end{array}$ & Literature review \\
\hline & Tveito and Eriksen ${ }^{44}$ & HIC - Norway & $\begin{array}{l}\text { All health care } \\
\text { workers }\end{array}$ & Literature review \\
\hline & Saxen and Virtanen ${ }^{39}$ & HIC - Finland & $\begin{array}{l}\text { All health care } \\
\text { workers }\end{array}$ & Literature review \\
\hline & Lee and Eriksen ${ }^{32}$ & HIC - Sweden & $\begin{array}{l}\text { All health care } \\
\text { workers }\end{array}$ & Literature review \\
\hline $\begin{array}{l}\text { 7. Legislation for work in } \\
\text { emergencies/disasters }\end{array}$ & Powell128 & HIC - USA & $\begin{array}{l}\text { All health care } \\
\text { workers }\end{array}$ & Commentary \\
\hline
\end{tabular}

Abbreviation: HIC, high-income country. 
adhere to. This was important for managers in identifying when to take action on absent employees and when not to. 2) Publicly reviewing records of employees with a frequent absence trend; and 3) ensuring that employees obtain prior request before absenting. ${ }^{26,36,47,48}$ The mechanism was mainly supported by existence of appropriate organizational culture for performance management and frequent audits to evaluate implementation of the policy.

Overall, changing organizational culture was associated with increased group performance among health care workers and reduced absenteeism. ${ }^{26,36,48}$

\section{Restriction or prohibition of private practice}

The practice was described in one out of 26 studies. In France, Spain, and the United Kingdom, restriction of absenteeism was implemented by introducing restrictions or prohibition of private practice among medical doctors. In Spain, public sector incentives were instituted to support the mechanism, while in the United Kingdom and Spain, public health providers were permitted to engage in private practice for a limited duration. ${ }^{49}$ This mechanism was only implemented for medical doctors.

\section{Changes in employment contracts}

Mechanisms that focused on changes in employment contracts from fixed short-term to permanent posts were described in one out of 26 of the studies in this review. Changes in employment contracts from fixed short-term to permanent posts were implemented in Finland by putting in place structures to recruit and finance permanent posts for health workers. In Peru, permanent salary-based employment was associated with lower absence rates among public health care workers. This measure was noted to increase job security, and hence resulted in increased motivation for attendance. Paradoxically, the measure was reported to increase absenteeism behavior in Costa Rica between 1995 and $2001 .{ }^{8}$ Kivisto et al ${ }^{41}$ report increased job security with the change from fixed short-term to permanent contracts, with employees subsequently exhibiting increased absence behavior and increased dual practice. Employee complacency as a result of having permanent contracts and poor monitoring of health workers hampered the mechanism.

\section{Multifaceted work interventions}

Multifaceted work mechanisms were reported in five out of the 26 studies. They were mainly implemented through administrative measures or controls. Their implementation involved a number of strategies. Examples include introducing a variety of changes over a 6-month period in the employee's supervision, assigned tasks, team members, working hours, or location. In Belgium for instance, recurrent changes in supervision, tasks, and moving from 8- to 12-hour shifts were institutionalized among nurses. ${ }^{42}$ Stone et $\mathrm{a}^{29}$ describe a different approach to the implementation of this mechanism in Holland, Spain, Germany, the United Kingdom, and Finland where the implementation of this measure involved managing attendance among all health care workers by using absence thresholds for workers. The thresholds were used to initiate a review by management and take the necessary actions to control absenteeism. In addition, health workers in Finland were provided with adequate information, for instance on health safety guidelines, to allow employees the autonomy to manage absence behavior. ${ }^{47}$ However, in Finland, nonpunitive control measures for instance verbal reminders of standards, written reminders, day-off with pay, and self-termination by employees were used. ${ }^{41}$ The provision of preventive and curative services addressing employee health and safety was another approach used within the work environment multifaceted measures. This was reported to increase dialogue and team work among health care workers, enabling employees to take immediate action when sick and increasing awareness of occupational safety. The studies reviewed measured the effect on absenteeism as a result of the work multifaceted measures after a period of 1 year, and so there were no immediate effects on absenteeism that were reported. The mechanism was mainly supported by involvement of employees in selection of strategies to increase attendance.

\section{Financial and nonfinancial interventions}

Financial and nonfinancial incentive regulatory measures were described in five out of 26 of the studies in this review. In the United Kingdom, financial and nonfinancial incentive regulatory mechanisms were implemented by rewarding good attendance for all health workers through conducting ceremonies to celebrate employees' outstanding loyalty. ${ }^{27}$ In the United States, rewarding good attendance for nurses was combined with coercive power. ${ }^{4,27}$ This involved three approaches: 1) bargaining with employees to attend their work to earn holidays in future; 2) buying back unused sick leave; and 3) giving nurses bonus payment and cash prizes for exemplary attendance. ${ }^{35}$ In the United States, a 20-week monitoring of employees reported up to $36 \%$ reduction in absence rates among nurse employees who were provided bonus checks for outstanding attendance. The mechanism was hindered by the limited capacity for long-term monitoring of 
attendance and the ineffective sanctions that were imposed for poor performance and absenteeism. On the other hand, the monetary incentives intended for health care workers at institutional level in Costa Rica, between 1995 and 2001, were instead used by management to buy equipment and this contributed to higher absence rates. ${ }^{8}$

\section{Health intervention mechanisms}

Mechanisms that focused on reducing ill-health and absence among health workers were described in seven of the 26 studies in this review. In the United States, the mechanism was implemented by vaccinating hospital employees against influenza. Weingarten et $\mathrm{al}^{33}$ and Kramer et $\mathrm{al}^{30}$ reported no difference in absence rates between the control and intervention group. However in Finland, Saxen and Virtanen $^{39}$ supported vaccination against influenza as being effective in reducing absenteeism. In a study done in the United States to measure the effect of back pain in direct patient care providers using early intervention with cognitive behavioral therapy, there was no statistical difference between the control and intervention group. ${ }^{2}$ In Norway, the health intervention involved an integrated health program, which involved, 1) physical exercise; 2) health information/ stress management training; and 3) practical examination of the workplace. The program was delivered by an aerobics instructor with nursing qualifications but was not effective in reducing sick leave among nurses. ${ }^{44}$ In Sweden, a 13-month exercise program delivered by individual nurses on the ward for at least 20 minutes reduced work absence. ${ }^{32}$ These health intervention mechanisms succeeded in reducing absenteeism where exercise programs were prolonged and immunization was given for seasonal epidemic prone diseases like influenza.

\section{Mandatory attendance and surveillance of absenteeism behavior during emergencies}

Lastly, in the United States, the legislation for work during public health disasters/emergencies was proposed as a mechanism aimed at compelling health workers to provide health care in emergencies. This mandated health care workers to provide care in emergencies (outbreaks) or face a range of sanctions. However, it encountered the challenge of ethical concerns regarding human liberties, ${ }^{28}$ which greatly hindered its implementation and success. This mechanism was described in one out of the 26 studies.

The contexts, study populations, variations in approach, and the outcomes of the absenteeism regulatory mechanisms for all included studies are summarized in Table 2.

\section{Factors that affected the implementation of absenteeism regulatory mechanisms in the health sector}

The key factors that were reported to enhance the success of the different regulatory mechanisms included both financial and nonfinancial mechanisms. The nonfinancial mechanisms particularly involving employees in setting attendance standards, scheduling their leave days, monitoring absenteeism, and indicating planned time off were found to lower absenteeism. Financial mechanisms such as performance-based incentives in the form of bonuses enhanced the success of regulatory mechanisms especially in contexts where absenteeism was prohibited. ${ }^{26,36}$ Allowing health workers to earn supplementary incomes was found to be an important factor in regulating absenteeism in settings where the health system had the ability to monitor and limit time for private practice. Additionally, the provision of adequate funding for both the private and public sectors was important in regulating absenteeism. Lack of systems to inadequately monitor employee attendance was a major factor in hindering the success of absenteeism regulatory mechanisms.

Table 3 summarizes the factors that may enhance existing or proposed mechanisms to regulate absenteeism in the health sector.

\section{Discussion}

Although literature on regulatory mechanisms mostly comes from HICs, absenteeism among health care workers is without a doubt a long-standing challenge for many health care organizations and governments in both HICs and LMICs. Possibly, governments in HICs have stronger stewardship for the health system and are also able to commit resources to evaluate existing regulatory mechanisms. Moreover, there has been a range of efforts by HICs governments and health care organizations to identify system problems and set standards for action, including early recognition of absenteeism using absenteeism record reviews. ${ }^{36,38,41}$

The majority of the absenteeism regulatory strategies in place focus on changing organizational behavior $^{26,31,32,36-38,41,47,48}$ by enforcing of organizational policies aimed at curbing absenteeism. In contexts where they have been implemented, the modification of organizational culture and reenforcing desired behavior resulted in both higher organizational performance and reduced absenteeism. ${ }^{46}$ In addition, organizational regulatory mechanisms have used surveillance, characterized by the practice of record keeping, frequent monitoring of employee absence behavior, detection of absences, and setting of thresholds for individual action, 
Table 2 Absenteeism regulatory mechanisms; variation in their application in different settings and outcomes

\begin{tabular}{|c|c|c|c|c|}
\hline $\begin{array}{l}\text { Absenteeism } \\
\text { regulatory } \\
\text { mechanisms }\end{array}$ & $\begin{array}{l}\text { Context (high- or } \\
\text { low-income countryl } \\
\text { rural-urban/private- } \\
\text { public) }\end{array}$ & $\begin{array}{l}\text { Study } \\
\text { population }\end{array}$ & $\begin{array}{l}\text { Variation in application of } \\
\text { regulatory mechanism }\end{array}$ & Outcomes \\
\hline \multicolumn{5}{|l|}{ I. Organizational policies } \\
\hline $\begin{array}{l}\text { I) Changing } \\
\text { organizational } \\
\text { culture and } \\
\text { leadership }\end{array}$ & $\begin{array}{l}\text { HIC - UK, the } \\
\text { Netherlands, USA } \\
\text { Australia }\end{array}$ & $\begin{array}{l}\text { All health care } \\
\text { workers } \\
\text { Health care } \\
\text { organizations }\end{array}$ & $\begin{array}{l}\text { Leaders transmit shared culture } \\
\text { that does not tolerate absenteeism } \\
\text { Set departmental standards with } \\
\text { exemplary conduct from employers } \\
\text { Involve employees in scheduling } \\
\text { leave days } \\
\text { Discussion with offenders, } \\
\text { encouraging them to improve } \\
\text { Counseling and follow-up of } \\
\text { employee conduct } \\
\text { Recognize improvement (reward } \\
\text { system) }\end{array}$ & $\begin{array}{l}\text { Increased group performance } \\
\text { Reduced absenteeism }\end{array}$ \\
\hline $\begin{array}{l}\text { 2) Instituting } \\
\text { absenteeism policy }\end{array}$ & $\begin{array}{l}\text { HIC - USA, Holland, } \\
\text { Germany, Spain, UK }\end{array}$ & $\begin{array}{l}\text { All health care } \\
\text { workers }\end{array}$ & $\begin{array}{l}\text { Institute policies for employees to } \\
\text { sign and adhere to } \\
\text { Publicly review records of } \\
\text { employees with frequent absence } \\
\text { trends } \\
\text { Requiring prior request before } \\
\text { absenting } \\
\text { Document and frequently audit } \\
\text { the attendance policy }\end{array}$ & $\begin{array}{l}\text { Reducing absenteeism } \\
\text { Indentify when to take action } \\
\text { on employees and when not to } \\
\text { do so } \\
\text { Evaluate policy implementation }\end{array}$ \\
\hline $\begin{array}{l}\text { 2. Restriction of private } \\
\text { practice }\end{array}$ & HIC - Spain, UK, France & Medical doctors & $\begin{array}{l}\text { Total stoppage of private practice } \\
\text { for agreed compensation } \\
\text { Public sector incentives instituted } \\
\text { (Spain) }\end{array}$ & $\begin{array}{l}\text { Work restriction to only the } \\
\text { public sector }\end{array}$ \\
\hline $\begin{array}{l}\text { 3. Changing employment } \\
\text { contracts from fixed } \\
\text { to permanent posts }\end{array}$ & HIC (Finland) & $\begin{array}{l}\text { All health care } \\
\text { workers in two } \\
\text { hospitals }\end{array}$ & None & $\begin{array}{l}\text { Higher absence rates for those } \\
\text { in permanent posts } \\
\text { Higher job security } \\
\text { Higher rates of dual practice in } \\
\text { public and private sectors }\end{array}$ \\
\hline \multicolumn{5}{|l|}{$\begin{array}{l}\text { 4. Work multifaceted } \\
\text { measures }\end{array}$} \\
\hline $\begin{array}{l}\text { I) Recurrent work } \\
\text { environment } \\
\text { changes }\end{array}$ & HIC - Belgium & Nurses & $\begin{array}{l}\text { Recurrent changes in supervisors, } \\
\text { tasks, shifts, colleagues, and work } \\
\text { location }\end{array}$ & $\begin{array}{l}\text { Job satisfaction increased } \\
\text { Less burnout among those on } \\
\text { I2-hour shifts compared to } \\
\text { 8-hour shifts } \\
\text { No changes in absence rates by } \\
\text { shift (I } 2 \text { vs } 8 \text { hour) } \\
\text { Reduction in sickness-related } \\
\text { absence } \\
\text { Changes perceived both as } \\
\text { positive and as negative appraisal }\end{array}$ \\
\hline \multirow[t]{3}{*}{$\begin{array}{l}\text { 2) Managing } \\
\text { attendance }\end{array}$} & $\begin{array}{l}\text { HIC - Holland, Spain, } \\
\text { Germany, UK, Finland }\end{array}$ & $\begin{array}{l}\text { All health care } \\
\text { workers }\end{array}$ & $\begin{array}{l}\text { Using an absence threshold for } \\
\text { workers to initiate a review by } \\
\text { management }\end{array}$ & Higher attendance \\
\hline & & & $\begin{array}{l}\text { Measures that involve action } \\
\text { thresholds are also referred to as } \\
\text { disciplinary controls }\end{array}$ & $\begin{array}{l}\text { Disciplinary measures have no } \\
\text { effect on absenteeism }\end{array}$ \\
\hline & & & $\begin{array}{l}\text { Setting individual trigger points for } \\
\text { occupational health visits/referral }\end{array}$ & $\begin{array}{l}\text { Ethical concerns regarding } \\
\text { employee privacy when being } \\
\text { subjected to mandatory } \\
\text { occupational health visit }\end{array}$ \\
\hline
\end{tabular}


Table 2 (Continued)

\begin{tabular}{|c|c|c|c|c|}
\hline $\begin{array}{l}\text { Absenteeism } \\
\text { regulatory } \\
\text { mechanisms }\end{array}$ & $\begin{array}{l}\text { Context (high- or } \\
\text { low-income countryl } \\
\text { rural-urban/private- } \\
\text { public) }\end{array}$ & $\begin{array}{l}\text { Study } \\
\text { population }\end{array}$ & $\begin{array}{l}\text { Variation in application of } \\
\text { regulatory mechanism }\end{array}$ & Outcomes \\
\hline \multirow[t]{2}{*}{$\begin{array}{l}\text { 3) Health and safety } \\
\text { initiatives }\end{array}$} & $\begin{array}{l}\text { HIC - Holland, Germany, } \\
\text { Spain, UK }\end{array}$ & $\begin{array}{l}\text { All health care } \\
\text { workers }\end{array}$ & $\begin{array}{l}\text { Return to work following absence, } \\
\text { Occupational health visits I-2 } \\
\text { months (with supervisor, client, } \\
\text { occupational health physician) } \\
\text { Counseling for poor attendance }\end{array}$ & $\begin{array}{l}\text { Ethical concerns regarding } \\
\text { occupational health physician } \\
\text { disclosure of employee's } \\
\text { information }\end{array}$ \\
\hline & HIC - USA & & $\begin{array}{l}\text { Providing booklets about common } \\
\text { expected injuries and illness }\end{array}$ & $\begin{array}{l}\text { Increased self-preventative } \\
\text { behavior and reduced doctor } \\
\text { consultation visits that reduce } \\
\text { absence behavior }\end{array}$ \\
\hline $\begin{array}{l}\text { 4) Allow individual } \\
\text { control of absences }\end{array}$ & HIC - Finland & $\begin{array}{l}\text { All health care } \\
\text { workers }\end{array}$ & $\begin{array}{l}\text { Provide adequate information } \\
\text { including guidelines to individual } \\
\text { employees } \\
\text { Allow them autonomy to manage } \\
\text { their absence behavior }\end{array}$ & Limited evidence of effectiveness \\
\hline $\begin{array}{l}\text { 5) Surveillance on } \\
\text { absenteeism } \\
\text { and referral to } \\
\text { occupational health } \\
\text { services }\end{array}$ & $\begin{array}{l}\text { HIC - Canada, Holland, } \\
\text { Germany, Spain, UK, } \\
\text { USA, Finland }\end{array}$ & $\begin{array}{l}\text { All health care } \\
\text { workers (excludes } \\
\text { physicians) }\end{array}$ & $\begin{array}{l}\text { Absenteeism monitoring, } \\
\text { detection, subjection to } \\
\text { occupation health visits, and self- } \\
\text { reporting on reasons for absence }\end{array}$ & $\begin{array}{l}\text { Prediction of seasonal absences } \\
\text { Improved rigor on monitoring } \\
\text { absenteeism from source } \\
\text { department/unit }\end{array}$ \\
\hline \multirow[t]{3}{*}{$\begin{array}{l}\text { 6) Health and safety } \\
\text { of staff }\end{array}$} & HIC - Finland, UK & $\begin{array}{l}\text { All health care } \\
\text { workers }\end{array}$ & $\begin{array}{l}\text { Conduct staff welfare discussions/ } \\
\text { meeting about personal life }\end{array}$ & Increases dialogue and team work \\
\hline & & & Prompt reporting of injuries & $\begin{array}{l}\text { For immediate action and to } \\
\text { shorten period of sickness } \\
\text { absence }\end{array}$ \\
\hline & & & $\begin{array}{l}\text { Providing preventative health } \\
\text { booklets (employee reading } \\
\text { materials) }\end{array}$ & $\begin{array}{l}\text { Increase awareness of } \\
\text { occupational safety }\end{array}$ \\
\hline \multicolumn{5}{|l|}{$\begin{array}{l}\text { 5. Financial and incentive } \\
\text { measures }\end{array}$} \\
\hline $\begin{array}{l}\text { I) Rewarding good } \\
\text { attendance } \\
\text { 2) Combining reward } \\
\text { and coercive power }\end{array}$ & HIC - UK, USA & $\begin{array}{l}\text { All health care } \\
\text { workers }\end{array}$ & $\begin{array}{l}\text { Providing rewards for good } \\
\text { attendance }\end{array}$ & $\begin{array}{l}\text { Had inconclusive effects, } \\
\text { sometimes reducing absenteeism, } \\
\text { but many times without effect }\end{array}$ \\
\hline $\begin{array}{l}\text { 6. Health intervention } \\
\text { mechanisms }\end{array}$ & $\begin{array}{l}\text { HIC - USA, Norway, } \\
\text { Finland, Sweden }\end{array}$ & $\begin{array}{l}\text { All health care } \\
\text { workers }\end{array}$ & $\begin{array}{l}\text { Vaccination against influenza } \\
\text { Exercise programs for health } \\
\text { workers }\end{array}$ & $\begin{array}{l}\text { Was effective in reducing } \\
\text { absenteeism where the } \\
\text { program was prolonged and } \\
\text { the immunization was given for } \\
\text { epidemic prone diseases }\end{array}$ \\
\hline $\begin{array}{l}\text { 7. Mandatory attendance } \\
\text { and surveillance } \\
\text { of health workers } \\
\text { absence behavior } \\
\text { during disasters }\end{array}$ & HIC - USA & $\begin{array}{l}\text { All health care } \\
\text { workers }\end{array}$ & $\begin{array}{l}\text { Compelling health care workers } \\
\text { to provide care in emergencies } \\
\text { (outbreaks) or face range of } \\
\text { sanctions }\end{array}$ & $\begin{array}{l}\text { Ethical concerns against public } \\
\text { liberties }\end{array}$ \\
\hline
\end{tabular}

Note: The table highlights the outcomes from the proposed or implemented regulatory mechanisms against absenteeism. A description of the context, study population, variation in approach, and the outcome was done for all included studies.

Abbreviation: HIC, high-income country.

which if breached set off a cascade of management actionoriented measures. Where absence monitoring or surveillance has been implemented, the practice has not been associated with successful management of absenteeism. We argue that surveillance on its own is not an absenteeism regulatory mechanism, but rather a process through which health care organizations or systems can track, quantify the magnitude of absenteeism, and plan appropriate regulatory strategies. Therefore, surveillance must be coupled with regular feedback to staff as well as appropriate rewards and sanctions. Also critical to its success is the involvement of employees in setting attendance standards, scheduling their leave days while indicating when they will have time off. This resonates with the importance of employee involvement in organiza- 
Table 3 Factors affecting the success of absenteeism regulatory mechanisms

\begin{tabular}{|c|c|c|}
\hline $\begin{array}{l}\text { Absenteeism regulatory } \\
\text { mechanisms }\end{array}$ & Variation of application & Factors influencing success or failure \\
\hline $\begin{array}{l}\text { I. Restriction/prohibition of } \\
\text { absenteeism }\end{array}$ & $\begin{array}{l}\text { Public sector incentives instituted } \\
\text { Allowable private practice for limited durations }\end{array}$ & $\begin{array}{l}\text { Institution of policy or guidelines } \\
\text { Compensation of net losses from private sector to } \\
\text { an assumable amount (incentives in form of bonuses) } \\
\text { tagged to work outputs } \\
\text { Bonus withheld for wrongful treatment } \\
\text { Supplementary earnings from private practice } \\
\text { Rigorous regulation on the part of the government's } \\
\text { health system }\end{array}$ \\
\hline $\begin{array}{l}\text { 2. Surveillance on } \\
\text { absenteeism and referral } \\
\text { for occupational health } \\
\text { visits }\end{array}$ & $\begin{array}{l}\text { Canadian hospitals provide } 562.5 \text { hours ( } 23 \text { days) } \\
\text { entitlement to sick bank for full-time employees for each } \\
\text { medical condition } \\
\text { Reoccurring absences for same medical condition deplete } \\
\text { the sick bank } \\
\text { Return to work postabsence and working consecutively } \\
\text { for all the scheduled shifts in a } 2 \text { I-day calendar restores } \\
\text { the sick bank } \\
\text { In the EU region, legislative changes were implemented } \\
\text { to change social security sickness absence to employer or } \\
\text { even employee. There is a requirement for organizations } \\
\text { to engage occupational health services (eg, the } \\
\text { Netherlands) or even for forced early retirement due to } \\
\text { cumulative absences (eg, Denmark) }\end{array}$ & $\begin{array}{l}\text { Cost of illness is transferred from taxpayer to the } \\
\text { employer who then has more control over employee }\end{array}$ \\
\hline $\begin{array}{l}\text { 3. Contract changes from } \\
\text { fixed term to permanent } \\
\text { posts }\end{array}$ & No variations described & $\begin{array}{l}\text { Structures to recruit and finance permanent posts } \\
\text { Absence worsened due to higher job satisfaction with } \\
\text { less rigorous monitoring }\end{array}$ \\
\hline $\begin{array}{l}\text { 4. Work multifaceted } \\
\text { (administrative measures) }\end{array}$ & $\begin{array}{l}\text { Independent changes over a 6-month period in either } \\
\text { of five dimensions (supervisor, task, colleagues, working } \\
\text { hours, or location). The effects of these are measured on } \\
\text { absenteeism over a I-year period }\end{array}$ & $\begin{array}{l}\text { Worker involvement in the selection of strategies to } \\
\text { increase attendance }\end{array}$ \\
\hline $\begin{array}{l}\text { 5. Financial/incentive } \\
\text { measures }\end{array}$ & $\begin{array}{l}\text { Ceremonies to celebrate employee loyalty annually } \\
\text { Bonus payments for exemplary employee attendance (no } \\
\text { specific suggestions of \% increase) }\end{array}$ & Adequate financing for public and private sectors \\
\hline $\begin{array}{l}\text { 6. Health intervention } \\
\text { mechanisms }\end{array}$ & $\begin{array}{l}\text { Vaccination of health workers against influenza } \\
\text { Exercise programs that aim at reducing work related ill- } \\
\text { health and absence among health workers }\end{array}$ & $\begin{array}{l}\text { Prolonging the programs and vaccination for seasonal } \\
\text { prolonged epidemics was key in the success of this } \\
\text { intervention }\end{array}$ \\
\hline 7. Organizational policies & $\begin{array}{l}\text { Policy changes in organizational culture including } \\
\text { attendance policies outlining disciplinary procedures for } \\
\text { absence, documenting the process for absence review, } \\
\text { monitoring, audit and disciplining, or even dismissal/forced } \\
\text { retirement } \\
\text { Culture on nonpunitive discipline }\end{array}$ & $\begin{array}{l}\text { Organizational culture for performance management } \\
\text { Existence of structures for implementation of policies at } \\
\text { organizational level } \\
\text { Frequent audits to evaluate implementation }\end{array}$ \\
\hline 8. Legislation & $\begin{array}{l}\text { Legislation for provision of sick bank that restricts amount } \\
\text { of allowable absence for sickness reasons } \\
\text { Legislation for mandatory occupational health visits upon } \\
\text { return from absence } \\
\text { Legislation on contract type to restrict private practice }\end{array}$ & Structures in place with strong leadership \\
\hline
\end{tabular}

tional cultural change as emphasized by $\operatorname{Harter}^{26}$ for good human resource management.

Policies requiring contract change from fixed short-term (temporary) to permanent posts would only be successful in LMICs if governments and health care systems strengthened their capacity to monitor and supervise employees. The implementation of comprehensive incentive packages would support this strategy because the increase in absence behavior when these mechanisms are implemented appears to be related to motivation to earn more income amid an environment of inadequate supervision of the health workforce.

The use of incentives such as rewarding good attendance and combining reward power with coercive power tended to 
have inconclusive effects, sometimes reducing absenteeism, but many times without effect. ${ }^{4,26,36}$ It is reasonable to expect that rewards and bonuses reinforce productive health care worker behavior. It is probable that some absence behavior is partly related to health workers' desire or need to earn supplemental income through engaging in other jobs or income generating activities. Moreover, financial incentives could resonate even better in LMICs contexts where payment structures in both the public and private sector are disparate and reportedly insufficient in both sectors. Instituting a favorably perceived remuneration package as compensation for nonprivate sector practice may be desirable but is far from ideal in LMICs settings where public financing to the sector is still inadequate. A good starting point for LMICs would be to explore the existing remuneration and incentive systems, particularly those in the private sector. Regarding nonfinancial incentives, the reported poor work environment characterized by limited equipment, medical supplies, and housing among other constrained infrastructural resources would need to be redressed to motivate health care workers.

However, it should be noted that any financial incentives provided might only be effective if they outweigh the financial benefits that accrue from having an extra job or activity away from the facility of regular employment. Given the limited health sector budgets in many countries, allocations to wages might not rise to meet the financial expectations of health workers indulging in lucrative private sector practice.

Legislation compelling health care workers to provide care during emergencies ${ }^{28}$ was proposed in response to higher than average absenteeism during health care emergencies. Although the practice may seem justified for the public's sake, it violated public liberties. Moreover, it only provides a short-term solution for absenteeism with limited evidence of its effectiveness in the long term. This could imply that a situational analysis is conducted to explore existing and desired incentive schemes for health care workers that work within the local context. Surveillance of absence behavior and feedback to providers and managers could be a viable option to implement at organizational level within both public and private sectors with relatively low costs for LMICs. It should, however, be coupled with rewards and sanctions if it is to be effective.

Prohibiting or limiting private practice as a regulatory measure in LMICs would only succeed following strengthened government regulatory frameworks to monitor and adequately supervise its workforce. Most LMICs are characterized by rapid private sector growth. This private sector not only offsets the service delivery weaknesses of the public sector but also introduces massive inequities in access. It is estimated that almost $55 \%{ }^{50}$ of health services in LMICs are provided by the private sector amid gross shortages of health workers. This implies that the two sectors compete for the limited human resources and create dynamic market forces, which drive dual practice as well as absenteeism. In Kenya, prohibition of dual practice led to mass migration of health workers from public to private sector. A revision of this policy later allowed only senior health professionals to engage in private practice and totally prohibited junior practitioners. ${ }^{51}$ Prohibiting private practice within LMICs would only be possible in the presence of well-resourced regulatory frameworks governing public and private sector service provision. Close monitoring is required to mitigate the unintended effects of prohibition and limiting private practice. Curran and Curran ${ }^{34}$ was not included in our review because it mentioned provider malpractices but did not focus directly on absenteeism.

\section{Conclusion}

Evidence on absenteeism regulation is scanty with most available studies describing the practice in HICs. Multiple strategies are most frequently undertaken in the management of health worker absence and their success is heavily influenced by the context within which they are applied. Gradual implementation of absenteeism policies for organizational cultural change appears to be critical for LMICs where absenteeism is the highest worldwide. There is need to explore alternative incentive strategies aimed at curbing absenteeism managed on site at the health facility level. Adequate monitoring systems are necessary to any strategy aimed at reducing absenteeism. The scope of measures and degree of autonomy allowed would vary by the skill level of personnel and technical level of the facility. The evidence on effectiveness of specific regulatory mechanisms in LMICs is limited.

\section{Acknowledgments}

The authors acknowledge the Alliance for Health Policy and Systems Research, World Health Organization, for supporting this review. The authors also acknowledge technical inputs from EPPI Center, Social Science Research Unit, Institute of Education, London, particularly Sandy Oliver and Makdarut Bangpan who peer reviewed the methodological sections of the protocol for this review and ran the searches. We acknowledge inputs from Charles Hongoro from the Health Systems Unit, South African Medical 
Research Council for peer review of the protocol for this review.

\section{Disclosure}

The authors report no conflicts of interest in this work.

\section{References}

1. Paringer L. Women and absenteeism: health or economics? Am Econ Rev. 1983;73(2):123-127.

2. Menzel NN, Robinson ME. Back pain in direct patient care providers: early intervention with cognitive behavioral therapy. Pain Manag Nurs. 2006;7(2):53-63.

3. Michie S, Williams S. Reducing work related psychological ill health and sickness absence: a systematic literature review. Occup Environ Med. 2003;60(1):3-9.

4. Rogers JE, Hutchins SG, Johnson BJ. Nonpunitive discipline: a method of reducing absenteeism. J Nurs Adm. 1990;20(7-8):41-43.

5. Chaudhury N, Hammer JS. Ghost doctors: absenteeism in Bangladeshi health facilities. World Bank Policy Research Working Paper. 2003:3065.

6. Rowe AK, de Savigny D, Lanata CF, Victora CG. How can we achieve and maintain high-quality performance of health workers in lowresource settings? Lancet. 2005;366(9490):1026-1035.

7. Muthama TM, Maina TM, Mwanje JI, Kibua TN. Absenteeism of Health Care Providers in Machakos District, Kenya: Incidence, Determinants, and Consequences. Kigali; Rwanda: Institute of Policy Analysis and Research; 2008.

8. García-Prado A, Chawla M. The impact of hospital management reforms on absenteeism in Costa Rica. Health Policy Plan. 2006;21(2):91-100.

9. Garrett AL, Park YS, Redlener I. Mitigating absenteeism in hospital workers during a pandemic. Disaster Med Public Health Prep. 2009;3(S2):S141-S147.

10. World Health Organisation. The World Health Report: 2006: Working Together for Health. Geneva, Switzerland: World Health Organisation; 2006.

11. Chen L, Evans T, Anand S, et al. Human resources for health: overcoming the crisis. The Lancet. 2004;364(9449):1984-1990.

12. Dieleman M, Shaw DM, Zwanikken P. Improving the implementation of health workforce policies through governance: a review of case studies. Hum Resour Health. 2011;9(10):10.

13. Dovlo D. Wastage in the health workforce: some perspectives from African countries. Hum Resour Health. 2005;3(1):6.

14. Sibbald B. Could reduced absenteeism help solve health-worker shortage? CMAJ. 2002;166(3):365-365-a.

15. Chan SS. Does vaccinating ED health care workers against influenza reduce sickness absenteeism? Am J Emerg Med. 2007;25(7):808-811.

16. Habyarimana J, Mbakile B, Pop-Eleches C. HIV/AIDS, ARV Treatment and Worker Absenteeism: Evidence Form a Large African Firm [Unpublished manuscript]. New York: Columbia university; 2008.

17. Lindelow M, Serneels P. The performance of health workers in Ethiopia: results from qualitative research. Soc Sci Med. 2006;62(9):2225-2235.

18. Thulesius HO, Grahn BE. Reincentivizing-a new theory of work and work absence. BMC Health Serv Res. 2007;7(1):100.

19. Chaudhury N, Hammer J, Kremer M, Muralidharan K, Rogers FH. Missing in action: teacher and health worker absence in developing countries. J Econ Perspect. 2006;20(1):91-116.

20. Lana AT, de León AC, García MT, Jaime AA. Smoking and sickness absence among public health workers. Public Health. 2005;119(2): 144-149.

21. Vidick S, Mairiaux P. [Long-term absenteeism due to lower back pain: the case of health care professionals in the hospital sector.] Sante Publique. 2007;20:S29-S37. French.

22. Ferrinho P, Van Lerberghe W, Fronteira I, Hipólito F, Biscaia A. Dual practice in the health sector: review of the evidence. Hum Resour Health. 2004;2(1):14.
23. Aldana SG, Pronk NP. Health promotion programs, modifiable health risks, and employee absenteeism. J Occup Environ Med. 2001;43(1):36-46.

24. Ngufor GF. Public service reforms and their impact on health sector personnel in Cameroon. ILO/WHO Public service reforms and their impact on health sector personnel: Case studies on Cameroon. 1999.

25. Ssengooba F, Rahman SA, Hongoro C, et al. Health sector reforms and human resources for health in Uganda and Bangladesh: mechanisms of effect. Hum Resour Health. 2007;5(3):1-13.

26. Harter TW. Minimizing absenteeism in the workplace: strategies for nurse managers. Nurs Econ. 2001;19(2):53-55.

27. Harden A, Garcia J, Oliver S, et al. Applying systematic review methods to studies of people's views: an example from public health research. J Epidemiol Community Health. 2004;58(9):794-800.

28. Powell T. Carrots and sticks: keeping healthcare workers on the job in a public health disaster. Am J Bioeth. 2008;8(8):20-21.

29. Stone PW, Du Y, Cowell R, et al. Comparison of nurse, system and quality patient care outcomes in 8-hour and 12-hour shifts. Med Care. 2006;44(12):1099-1106.

30. Kramer JS, Durham C, Schroeder T, Garrelts JC. Effectiveness of halfdose versus full-dose influenza vaccine in health care workers. $\mathrm{Am} \mathrm{J}$ Health Syst Pharm. 2006;63(21):2111-2115.

31. Nelson A, Matz M, Chen F, Siddharthan K, Lloyd J, Fragala G. Development and evaluation of a multifaceted ergonomics program to prevent injuries associated with patient handling tasks. Int J Nurs Stud. 2006;43(6):717-733.

32. Lee JB, Eriksen LR. The effects of a policy change on three types of absence. J Nurs Adm. 1990;20(7-8):37-40.

33. Weingarten S, Staniloff H, Ault M, Miles P, Bamberger M, Meyer RD. Do hospital employees benefit from the influenza vaccine? J Gen Intern Med. 1988;3(1):32-37.

34. Curran MA, Curran KE. Gambling away absenteeism. $J$ Nurs Adm. 1987;17(12):28-31.

35. Stephens TA, Burroughs WA. An application of operant conditioning to abseentism in a hospital setting. J Appl Psychol. 1978;63(4):518.

36. Johnson CJ, Croghan E, Crawford J. The problem and management of sickness absence in the NHS: considerations for nurse managers. $J$ Nurs Manag. 2003;11(5):336-342.

37. Gaudine AP, Saks AM. Effects of an absenteeism feedback intervention on employee absence behavior. J Organ Behav. 2001;22(1):15-29.

38. Donovan TL, Moore KM, VanDenKerkhof EG. Employee absenteeism based on occupational health visits in an urban tertiary care Canadian hospital. Public Health Nurs. 2008;25(6):565-575.

39. Saxen H, Virtanen M. Randomized, placebo-controlled double blind study on the efficacy of influenza immunization on absenteeism of health care workers. Pediatr Infect Dis J. 1999;18(9):779-783.

40. Virtanen M, Kivimäki M, Elovainio M, Vahtera J, Ferrie JE. From insecure to secure employment: changes in work, health, health related behaviours, and sickness absence. Occup Environ Med. 2003;60(12):948-953.

41. Kivistö S, Verbeek JH, Hirvonen M, Varonen H. Return-to-work policies in Finnish occupational health services. Occup Med (Lond). 2008;58(2):88-93.

42. Verhaeghe R, Vlerick P, Gemmel P, Maele GV, Backer GD. Impact of recurrent changes in the work environment on nurses' psychological well-being and sickness absence. $J A d v$ Nurs. 2006;56(6):646-656.

43. Gundewall B, Liljeqvist M, Hansson T. Primary prevention of back symptoms and absence from work: a prospective randomized study among hospital employees. Spine. 1993;18(5):587-594.

44. Tveito TH, Eriksen HR. Integrated health programme: a workplace randomized controlled trial. JAdv Nurs. 2009;65(1):110-119.

45. Lee Lc, Yang KP, Chen TY. A quasi-experimental study on a quality circle program in a Taiwanese hospital. Int J Qual Health Care. 2000;12(5):413-418.

46. Michie S, West MA. Managing people and performance: an evidence based framework applied to health service organizations. Int J Manag Rev. 2004;5(2):91-111.

47. Whitaker SC. The management of sickness absence. Occup Environ Med. 2001;58(6):420-424. 
48. McDonald JM, Shaver AV. An absenteeism control program. J Nurs Adm. 1981;11(5):13-18.

49. Gonzalez P. Should physicians' dual practice be limited? An incentive approach. Health Econ. 2004;13(6):505-524.

50. Hanson K, Berman P. Private health care provision in developing countries: a preliminary analysis of levels and composition. Health Policy Plan. 1998;13(3):195-211.
51. Berman P, Cuizon D. Multiple public-private jobholding of health care providers in developing countries: an exploration of theory and evidence. London, UK: Department for International Developmnent Health Systems Resource Centre Publication; 2004.

52. Allen DG, Shore LM, Griffeth RW. The role of perceived organizational support and supportive human resource practices in the turnover process. J Manage. 2003;29(1):99-118.

\section{Publish your work in this journal}

The Journal of Healthcare Leadership is an international, peer-reviewed, open access journal focusing on leadership for the health profession. The journal is committed to the rapid publication of research focusing on but not limited to: Healthcare policy and law; Theoretical and practical aspects healthcare delivery; Interactions between healthcare and society and evidence-based practices;
Interdisciplinary decision-making; Philosophical and ethical issues; Hazard management; Research and opinion for health leadership; Leadership assessment. The manuscript management system is completely online and includes a very quick and fair peer-review system. Visit http://www.dovepress.com/ testimonials.php to read real quotes from published authors. 